\title{
Prevalence of Occult Hepatitis B Infection among HIV Infected Patients at an Innercity Clinic
}

Rajat Nog*, Kumara Singaravelu and Sharon Mannheimer

Columbia University Medical Center affiliation at Harlem Hospital Center Manchester, CT, USA

\begin{abstract}
Considering higher morbidity and mortality associated with HIV/HBV coinfected patients compared to monoinfected patients, it is imperative to determine the prevalence of occult HBV (OHB) infection, in such population.630 unique HIV-infected patients, during the defined study period, were screened for evidence of occult HBV infection serology. 82 patients $(13 \%)$ were found to have evidence suggestive of OHB infection of which 57 had HBV DNA testing available and comprised the final study population. Data on demographic variables, Hepatitis $\mathrm{C}$ antibody status, antiretroviral therapy (ARV), CD4 count and HIV viral load was also collected. Among the final study population, $7 \%(n=4)$ patients met the OHB definition. All $4(100 \%)$ with OHB had HIV RNA levels $>50$ copies $/ \mathrm{ml}$. OHB was found in $4(22 \%)$ of 18 patients not on ARV, but in none of 39 patients on ARV $(p=0.007)$. All patients on ARV were on a regimen with anti HBV activity. $75 \%$ of patients with OHB tested positive for HCV compared to $47 \%$ in isolated anti HBc positive but HBV DNA negative population $(p=0.58)$. With an OHB prevalence of $7 \%$ in our community clinic, clinicians should have a high index of suspicion for OHB among HIV patients whose hepatitis panel is positive only for anti HBc only and start them on HAART regimen containing ARVs with anti-HBV activity.
\end{abstract}

Keywords: Occult Hepatitis B; HIV

\section{Background}

More than two decades since the recognition of Occult Hepatitis $\mathrm{B}$ virus $(\mathrm{OHB})$ infection, there is still limited information in terms of its prevalence, clinical significance, pathological and infective potential and the need for treatment and follow up. Occult HBV infection has been defined as the presence of Core alone positive HBV serology [positive Hepatitis B core antibody (anti $\mathrm{HBc}$ ) with negative Hepatitis B surface antigen (HBs Ag) and surface antibody (HBs $\mathrm{Ab}$ )], along with detectable HBV DNA. It is a form of chronic HBV infection. Occult hepatitis B has been reported in patients with chronic hepatitis $\mathrm{C}$ infection, cirrhosis, end stage renal disease on dialysis, and Human Immunodeficiency virus (HIV) infection $[1,2]$.

The presence of chronic Hepatitis B co-infection is associated with greater morbidity and mortality among HIV-infected patients [3-5]. It is important to know the prevalence of occult or core alone positive Hepatitis B coinfection in HIV-infected patients as it is another form of chronic Hepatitis B infection, which may also potentially negatively affect patient outcomes. Limited published research data in one of the seminal studies in United States on HIV positive but ARV naive patients by Shire et al. [6] suggested a prevalence of $11 \%$. However the prevalence of occult HBV infection among HIV-infected populations in this era of HAART has not been studied before.

\section{Objective}

To determine the prevalence and patient characteristics of occult hepatitis B infection in HIV infected patients attending an outpatient HIV clinic in New York City.

\section{Methods}

Harlem Hospital Center Infectious Diseases Clinic, located in the Harlem neighborhood of New York City, NY, has a large HIV outpatient clinic with over 1000 patients seen annually. Patient information from all visits is stored in an electronic database (Discoverer Plus). After obtaining Institutional review board (IRB) approval from Columbia University Medical Center this electronic database was screened to identify potential study participants. A total of 630 unique HIV-infected patients had a clinic visit during the defined study period - June 1, 2007 and January 31st 2009. Of these 630 patients, $82(13 \%)$ were found to have serological evidence suggestive of occult HBV infection (HBsAg-, HBsAb-, anti $\mathrm{HBc}+$ ). Serologic evaluation for $\mathrm{HBsAg}$, anti-HBs, and total anti-HBc was performed using enzyme immunoassay test kits from Abbott Laboratories (Abbott Park, IL), in accordance with manufacturer's specifications). HBV DNA testing was available on 57 patients and they comprised the final study population in whom a more detailed chart review was performed. Samples were tested for HBV DNA using the Roche COBAS Amplicor HBV Monitor assay, which is a PCR amplification-based assay). In addition to demographic variables, information on Hepatitis $\mathrm{C}$ antibody (HCV Ab), antiretroviral therapy (ARV), most recent CD4 count and HIV viral load were collected and entered into a MS Excel Spreadsheet. Statistical analysis was performed using EpiInfo 3.5.3.

\section{Results}

Among the final study population $(\mathrm{n}=57)$ (Table 1$)$, the majority were males $(n=36,63.2 \%)$, African American $(n=50,87.7 \%)$, Hispanic $(\mathrm{n}=6,10.5 \%$ and Caucasian $(\mathrm{n}=1,1.7 \%)$, with a mean age of $48.7 \pm$ 6.2yrs. In terms of their HIV infection, $70.2 \%$ were on ARV $(n=39)$, $75.4 \%$ had CD 4 cell counts $>200$ cells $/ \mathrm{mm} 3(\mathrm{n}=43)$, and $40.4 \%$ had HIV RNA levels $<50(n=23)$. Nearly half of the study population $(n=28$, $49 \%)$ tested positive for HCV antibodies. Only $7 \%(n=4)$ of the final study population met the definition of occult HBV infection. Of these patients with occult HBV infection, 50\% $(n=2)$ were males, $100 \%(n=4)$

${ }^{*}$ Corresponding author: Rajat Nog, Columbia University Medical Center affiliation at Harlem Hospital Center Manchester, CT, USA, E-mail: drrajatnog@hotmail.com Received June 12, 2013; Accepted October 11, 2013; Published October 16, 2013

Citation: Nog R, Singaravelu K, Mannheimer S (2013) Prevalence of Occult Hepatitis B Infection among HIV Infected Patients at an Innercity Clinic. J AIDS Clin Res 4: 252. doi: 10.4172/2155-6113.1000252

Copyright: @ 2013 Nog R, et al. This is an open-access article distributed under the terms of the Creative Commons Attribution License, which permits unrestricted use, distribution, and reproduction in any medium, provided the original author and source are credited. 
Citation: Nog R, Singaravelu K, Mannheimer S (2013) Prevalence of Occult Hepatitis B Infection among HIV Infected Patients at an Innercity Clinic. J AIDS Clin Res 4: 252. doi: 10.4172/2155-6113.1000252

Page 2 of 3

\begin{tabular}{|l|c|c|}
\hline & $\mathbf{n}$ & $\%$ \\
\hline Male Gender & 36 & 62.2 \\
\hline Race/ Ethnicity & & \\
\hline African American & 50 & 87.8 \\
\hline Hispanic & 6 & 10.5 \\
\hline Caucasian & 1 & 1.7 \\
\hline Age (mean \pm s.d.) & $48.7 \pm 6.2$ yrs & \\
\hline On antiretroviral medications & 39 & 70.2 \\
\hline CD4 cell count >200 & 43 & 75.4 \\
\hline Mean CD4 cell count & 461.4 & \\
\hline HIV RNA level <50 & 30 & 52.6 \\
\hline HCV co-infection & 27 & 47.4 \\
\hline Occult HBV & 4 & 7 \\
\hline
\end{tabular}

Table 1: Descriptive Characteristics of Study Population ( $N=57)$.

\begin{tabular}{|l|c|c|}
\hline & $n$ & $\%$ \\
\hline Male & 2 & 50 \\
\hline Female & 2 & 50 \\
\hline African American & 4 & 100 \\
\hline HCV antibody+ & 3 & 75 \\
\hline Mean CD4 cell count & $408 \pm 280$ cells $/ \mathrm{mm}^{3}$ \\
\hline CD4 $<200$ & 2 & 50 \\
\hline CD4 $>200$ & 0 & 50 \\
\hline VL $<50$ & 4 & 0 \\
\hline VL $>50 \%$ & 0 & 100 \\
\hline On ARV & 4 & 0 \\
\hline Not on ARV & 2 & 100 \\
\hline
\end{tabular}

Table 2: Characteristics of patients with HBV DNA positive $(\mathrm{N}=4)$

were African American, mean CD4 count was $408 \pm 280$ cells $/ \mathrm{mm} 3$, $100 \%(\mathrm{n}=4)$ had HIV RNA levels $>50$ copies $/ \mathrm{ml}, 100 \%(\mathrm{n}=4)$ were not on ARV (Table 2). Overall, detectable HBV DNA was found in 4 (22\%) of 18 patients not on ARV, but in none of the patients who were on ARV $(\mathrm{n}=39)(\mathrm{p}=0.007)$. All patients on ARV $(\mathrm{n}=39)$ were on a regimen with NRTI backbone including Tenofovir, Emtricitabine or Lamivudine that had anti HBV activity. $75 \%$ of patients with occult HBV tested positive for $\mathrm{HCV}$ compared to $47 \%$ in isolated anti $\mathrm{HBc}$ positive but HBVDNA negative population $(\mathrm{p}=0.58)$.

\section{Conclusions and Discussion}

HBV infection has traditionally been associated with HIV as a coinfection as they share the same transmission modes [3,5,7-9]. The prevalence of occult Hepatitis B varies significantly between geographical regions $(<10 \%$ to up to $25 \%)$ [5], among various patient populations tested as well as the sensitivity of the assay used $[3,4,10,11]$.Though the overall prevalence of occult $\mathrm{HBV}$ in our community clinic (7\%) is lower than the historical reported prevalence of $11 \%$, the prevalence was much higher (22\%) among hose not on ARV. This is concerning as occult HBV has not only been associated with increased liver enzymes and pathology but also implicated with $\mathrm{HBV}$ transmission; reactivation of HBV and hepatocellular carcinoma (HCC) [3,12-15].

The use of ARV in this study was significantly associated with the lack of detectable HBV viremia. None of the patients on ARV tested positive for occult infection. All of the patients on ARV were on a regimen which was active against Hepatitis $\mathrm{B}$, with regimens including Lamivudine, Tenofovir and Emtricitabine. This actually might have caused HBV suppression and contributed to a lower prevalence in our study as compared to the historical prevalence.

A high proportion of patients with occult $\mathrm{HBV}$ infection also tested positive for $\mathrm{HCV} \mathrm{Ab}(75 \%)$. This increased prevalence of occult HBV with HIV and HCV coinfection has been reported before [16-18]. It has been postulated that $\mathrm{HCV}$ either facilitates or induces mutation in HBV resulting in inefficient replication of $\mathrm{HBV}$, a phenomenon known as interference and this inhibitory effect is mediated by HCV core protein [19].

Apart from viral factors, host factors like defective or insufficient immune response to infection due to $\mathrm{HIV} / \mathrm{HCV}$ and/or immunosuppressive state have also been suggested for this discrepancy in HBV serology [20]. Finally Occult HBV infection has also been reported to adversely affect the treatment response to HCV though this effect is debatable [21].

Our study did not find any association between presence of occult HBV infection and CD4 Counts unlike an association with lower CD4 counts reported by Stuart et al. [22]. The strength of our study was a mixed population in terms of age and sex distribution. Also our study population included HIV-infected individuals both on and off ARVs. However our study mainly consisted of African American population, only looked into the presence/absence of HBV DNA at the time of positive core only Hepatitis B serology, and did not include long term follow-up of the study populations.

Prior studies have documented variable hepatitis B viremic states in other HIV-infected populations affected by multiple factors such as presence of other immunosuppressive states, compliance with ARVs, presence/absence of $\mathrm{HCV}$ infection and particular genotype, response to $\mathrm{HCV}$ treatment, HBV genotype, and HDV coinfection. Also since the study included only patients that had total HBV serology, including DNA levels available and excluded the rest, the final prevalence could have been an underestimate.

In conclusion, clinicians should have a high index of suspicion for occult HBV among HIV-infected patients whose hepatitis panel is positive only for Hepatitis B core antibody (anti $\mathrm{HBc}$ ). All such patients should be screened with HBV DNA, particularly if they also have HCV co-infection. It is now recommended that HIV-infected patients who need treatment for hepatitis B should be started on a full HAART regimen containing ARVs with anti-HBV activity.

\section{References}

1. Re III VL, Frank I, Gross R, Dockter J, Linnen JM, et al. (2007) Prevalence, risk factors, and outcomes for occult hepatitis B virus infection among HIV-infected patients. J Acquir Immune Defic Syndr 44: 315-320.

2. Mphahlele MJ, Lukhwareni A, Burnett RJ, Moropeng LM, Ngobeni JM (2006) High risk of occult hepatitis B virus infection in HIV-positive patients from South Africa. J Clin Virol 35: 14-20.

3. Kourtis AP, Bulterys M, Hu DJ, Jamieson DJ (2012) HIV-HBV coinfection--a global challenge. N Engl J Med 366: 1749-1752.

4. Colin JF, Cazals-Hatem D, Loriot MA, Martinot-Peignoux M, Pham BN, et al. (1999) Influence of human immunodeficiency virus infection on chronic hepatitis B in homosexual men. Hepatology 29: 1306-1310.

5. Thio CL, Seaberg EC, Skolasky R Jr, Phair J, Visscher B, et al. (2002) HIV-1, hepatitis $B$ virus, and risk of liver-related mortality in the Multicenter Cohort Study (MACS). Lancet 360: 1921-1926.

6. Shire NJ, Rouster SD, Rajicic N, Sherman KE (2004) Occult hepatitis B in HIVinfected patients. J Acquir Immune Defic Syndr 36: 869-875.

7. Alter MJ (2006) Epidemiology of viral hepatitis and HIV co-infection. J Hepato 44: S6-9.

8. Santiago-Munoz P, Roberts S, Sheffield J, McElwee B, Wendel GD Jr (2005) Prevalence of hepatitis $B$ and $C$ in pregnant women who are infected with human immunodeficiency virus. Am J Obstet Gynecol 193: 1270-1273. 
Citation: Nog R, Singaravelu K, Mannheimer S (2013) Prevalence of Occult Hepatitis B Infection among HIV Infected Patients at an Innercity Clinic. J AIDS Clin Res 4: 252. doi: 10.4172/2155-6113.1000252

9. Bonacini M, Louie S, Bzowej N, Wohl AR (2004) Survival in patients with HIV infection and viral hepatitis B or C: a cohort study. AIDS 18: 2039-2045.

10. Neau D, Winnock M, Jouvencel AC, Faure M, Castera L, et al. (2005) Occult hepatitis B virus infection in HIV-infected patients with isolated antibodies to hepatitis B core antigen: Aquitaine cohort, 2002-2003. Clin Infect Dis 40: 750753.

11. Hofer M, Joller-Jemelka HI, Grob PJ, Luthy R, Opravil M (1998) Frequent chronic hepatitis $B$ virus infection in HIV-infected patients positive for antibody to hepatitis B core antigen only. Swiss HIV Cohort Study. Eur J Clin Microbiol Infect Dis 17: 6-13.

12. Shiota G, Oyama K, Udagawa A, Tanaka K, Nomi T, et al. (2000) Occult hepatitis $B$ virus infection in $\mathrm{HBs}$ antigen-negative hepatocellular carcinoma in a Japanese population: involvement of HBx and p53. J Med Virol 62: 151-158.

13. Thiers V, Nakajima E, Kremsdorf D, Mack D, Schellekens H, et al. (1988) Transmission of hepatitis $B$ from hepatitis-B-seronegative subjects. Lancet 2 : 1273-1276.

14. Hoofnagle JH, Seeff LB, Bales ZB, Zimmerman HJ (1978) Type B hepatitis after transfusion with blood containing antibody to hepatitis $\mathrm{B}$ core antigen. $\mathrm{N}$ Engl J Med 298: 1379-1383.

15. Uchida T, Shimojima S, Gotoh K, Shikata T, Mima S (1994) Pathology of livers infected with "silent" hepatitis B virus mutant. Liver 14: 251-256.

16. Weber B, Melchior W, Gehrke R, Doerr HW, Berger A, et al. (2001) Hepatitis
B virus markers in anti-HBc only positive individuals. J Med Virol 64: 312 319

17. Gandhi RT, Wurcel A, Lee H, McGovern B, Boczanowski M, et al. (2003) Isolated antibody to hepatitis B core antigen in human immunodeficiency virus type-1-infected individuals. Clin Infect Dis 36: 1602-1605.

18. Habibollahi P, Safari S, Daryani NE, Alavian SM (2009) Occult hepatitis B infection and its possible impact on chronic hepatitis $C$ virus infection. Saudi J Gastroenterol 15: 220-224.

19. Morsica G, Ancarani F, Bagaglio S, Maracci M, Cicconi P, et al. (2009) Occult Hepatitis B Virus Infection in a Cohort of HIV-Positive Patients:Correlation with Hepatitis C Virus Coinfection, Virological and Immunological Features. Infection 37: 445-449.

20. Jardi R, Rodriguez F, Buti M, Costa X, Cotrina M, et al. (2001) Role of hepatitis $B, C$, and $D$ viruses in dual and triple infection: influence of viral genotypes and hepatitis $B$ precore and basal core promoter mutations on viral replicative interference. Hepatology 34: 404-410.

21. Fukuda R, Ishimura N, Niigaki M, Hamamoto S, Satoh S, et al. (1999) Serologically silent hepatitis B virus coinfection in patients with hepatitis $C$ virus-associated chronic liver disease: clinical and virological significance. $J$ Med Virol 58: 201-207.

22. Cohen Stuart JW, Velema M, Schuurman R, Boucher CA, Hoepelman AI (2009) Occult hepatitis B in persons infected with HIV is associated with low CD4 counts and resolves during antiretroviral therapy. J Med Virol 81: 441-445. 